J. Perinat. Med. 13 (1985) 239

\section{Reduced colonization of newborns with group B streptococci following washing of the birth canal with chlorhexidine*}

\author{
K. K. Christensen, A. K. Dykes, P. Christensen**
}

Department of Obstetrics and Gynecology, University Hospital, Lund, and **Department of Medical Microbiology, University of Lund, Sweden

\section{Introduction}

Septicemia with group B streptococci (GBS) in the neonatal period is a serious infection with a high mortality rate [2]. In the early onset form, which constitutes about $80 \%$ of the cases in Sweden [4], the infants contract the bacteria from the birth canal during labor [2]. Possible measures for prevention include active or passive immunoprophylaxis or administration of penicillin to mothers or infants $[2,4]$. So far, none of these possibilities have been generally accepted.

We have previously studied the possibility of suppressing GBS in the birth canal by washing with chlorhexidine. GBS were found to be extremely sensitive to the compound [3], and vaginal washing diminished the recovery of GBS effectively from parturients [6]. The present study concerned the effect of vaginal washing on the colonization of newborns with GBS.

\section{Patients and methods}

The Ethical Review Committee at the University of Lund confined chlorhexidine washing to parturients that were known carriers of GBS.

* Supported by grant no. 16X-06559 from the Swedish Medical Research Council, the Expressen Prenatal Research Foundation, Allmänna BB Minnesfound and the Medical Faculty, University of Lund.
The study group was therefore defined as chronic GBS carriers, I. e. women with positive selective broth cultures from urethra and/or cervix in the 32 to 36 gestational weeks, as well as on admittance to the delivery ward. Washing was performed in 18 patients, and 33 chronic carriers served as controls. During the study period (November 1983 to June 1984), screening for GBS carriage was also performed in 945 consecutive patients on arrival to the delivery ward. Written consent was obtained from all patients included in this study after the nature of the procedures had been fully explained in the antenatal clinics between gestational weeks 20-30.

For vaginal washing, the cervix was visualized with a speculum and depressor. A sterile compress was steeped in $2 \mathrm{~g} / \mathrm{l}$ chlorhexidine acetate (ICI Ltd, U. K.: supplied by ACO Läkemedel, Sweden) and the fornices washed by turning the compress three times around the cervix. The washing was extended to the vaginal walls using spiral movements. After repeating this procedure twice with new compresses, a fourth compress was pressed against the cervical orifice to let chlorhexidine enter the orifice. A fifth compress was pressed against the urethral orifice and by sweeping downwards used for washing the labia minora and the introitus. Washing was performed irrespective of ruptured membranes or not and repeated every sixth hour 
until delivery. However, one patient who was delivered immediately after the first washing was excluded from the investigation, as were patients subjected to cesarean section. The washing procedure took about 5 minutes and was performed by the midwife on duty.

All parturients were given a shower, using a soap containing chlorhexidine (Hibiscrub ${ }^{\circledR}, \mathrm{ICI}$ Ltd). External washing of the lower abdomen and external genitalia was performed in all parturients by the midwife using chlorhexidine $2 \mathrm{~g} /$ 1. Nursing of the newborns included desinfection of the umbilical area three times daily with $70 \%$ ethanol containing $5 \mathrm{~g}$ chlorhexidine $/ 1$.

Cultures were collected from the external ear, throat and umbilicus of all infants within 5 minutes of birth and at day 4 of life. The bacteriological methods have been described previously [5].

The Chi-square test with Yate's correction or Fischer's exact test were used to compare GBS colonization data. Patient demographics were compared by Student's t-test.

\section{Results}

Among the infants of the chlorhexidine-washed mothers, $22 \%$ became colonized with GBS at birth in contrast to $52 \%$ of the infants to the chronic GBS carriers serving as controls $(p<0.05)$. Presence of GBS in the ear and umbilicus was significantly reduced in the chlorhexidine group, whereas the throat colonization did not differ significantly between the two groups. Furthermore, the proportions or infants harboring GBS at day 4 of life were similar in the two groups (Tab. I). Parity, complications during pregnancy or delivery, hours from onset of labor to delivery or infant weight and gestational age did not differ between the groups.

Of the 945 women screened for GBS on arrival to the delivery ward, 164 harbored GBS in the urogenital tract. Among the carriers, 54 (33\%) gave birth to infants acquiring GBS at birth. The proportion of infants of the chronic carrier controls colonized at birth, $52 \%$ was significantly higher $(p<0.05)$ than the colonization rate in the washing group, $22 \%$. At day 4 of life, $34(21 \%)$ of the infants of the 164 GBS carriers were culture positive and this was not significantly different from the study or the control groups.

\section{Discussion}

Infants from chronic GBS carriers were more frequently colonized with GBS at birth than infants from unselected GBS carriers. This finding might reflect the fact that the risk of acquisition of GBS by infants increases with the quantity of GBS in the birth canal [1]. Vaginal washing with chlorhexidine suppressed the transfer of GBS from mother to infant among the chro-

Tab. I. Colonization of infants from chronic GBS carriers.

\begin{tabular}{|c|c|c|c|c|c|}
\hline \multirow[t]{2}{*}{ Time - Site } & \multicolumn{2}{|c|}{ No. of infants to chlorhexidine-washed } & \multicolumn{2}{|c|}{ No. of infants to controls } & \multirow[t]{2}{*}{ p-value } \\
\hline & Colonized & Not colonized & Colonized & Not colonized & \\
\hline \multicolumn{6}{|l|}{ At birth } \\
\hline - throat & 2 & 16 & 9 & 24 & n.s.* \\
\hline - ear & 2 & 16 & 11 & 22 & 0.021 \\
\hline - umbilicus & 1 & 17 & 10 & 23 & 0.001 \\
\hline$-1-3$ sites & 4 & 14 & 17 & 16 & 0.031 \\
\hline \multicolumn{6}{|l|}{ At day 4 of life } \\
\hline$-1-3$ sites & 3 & 14 & 6 & 25 & n.s.* \\
\hline
\end{tabular}

N. . $^{*}=$ not significantly different $(p>0.05)$. 
nic carriers from 52 to $22 \%$. Colonization of ear and umbilicus was reduced indicating that infants born to chlorhexidine-washed mothers were less contaminated. In laboratory experiments, the capacity of a given GBS strain to kill mice is highly dose dependent [7]. One may assume that the infants benefit from the washing not only because fewer will be colonized but also because the few individuals colonized will receive a smaller dose of bacteria.

At day 4, no significant differences were seen between infants of chlorhexidine washed mothers and the control infants. Evidently, the size of the present study was not sufficiently large to make any definite conclusion about colonization at day 4.

In a previous study also performed at our clinic the proportion of mothers harboring GBS at delivery was similar to the frequency found in the present study, 16\% [5]. Nevertheless, the colonization rate among infants of unselected GBS carriers was $51 \%$, compared to the present $33 \%$. We refer the diminished colonization rate to the new hygienic routines introduced 3 years ago at the department, i. e. the shower with chlorhexidine soap before delivery. This measure was undertaken to diminish the frequency of postoperative infections following cesarean section.

We conclude that the present results raise hope for the design of a simple measure for control of early onset GBS disease in newborns. If necessary, the chlorhexidine solution or the washing procedure could be changed to increase the effectivity of the method. Studies of clinical infection rates among newborns following chlorhexidine washing are now indicated.

\section{Summary}

Possible measures for prevention of neonatal group B streptococcal (GBS) septicemia include active or passiv immunoprophylaxis and administration of penicillin to mothers and infants. In a previous study we have found GBS to be extremely sensitive to chlorhexidine. Furthermore vaginal washing with chlorhexidine diminished the recovery of GBS from parturients. In order to study the effect of chlorhexidine washing upon the colonization of newborns, a study group of chronic GBS carriers, i.e. women who were GBS positive in the $32-36$ gestational week as well as during labor was selected. In 18 of these females chlorhexidine washing was performed prior to delivery while 33 chronic carriers served as controls. Screening during labor was performed in 945 consecutive patients. Cultures were collected from the external ear, throat and umbilicus of all infants within 5 minutes of birth and at day 4 of life.
At birth $22 \%$ of the infants of the chlorhexidine washed mothers were colonized with GBS, in contrast to $52 \%$ of the infants from the chronic GBS carriers $(p<0.05)$. The proportion of infants harboring GBS at day 4 were similar in the two groups (Tab. I). Among the 945 consecutively screened women, 164 harbored GBS and $54(33 \%)$ of their 164 infants were colonized at birth. The colonization rate of the infants from chronic GBS carriers was significantly higher, 17 of 33 infants $(p<0.05)$. This may reflect that the risk of contracting GBS by infants increases with the quantity of GBS in the birth channel. Vaginal washing with chlorhexidine suppressed the transfer of GBS from mother to infant among the chronic GBS carriers. No side-effects of the washing procedure were noted. The present results raise hope for the design of a simple measure for control of early onset neonatal GBS disease.

Keywords: Chlorhexidine, group B streptococci, neonatal infection.

\section{Zusammenfassung}

Verminderte Kolonisierung von Neugeborenen mit Streptokokken der Gruppe B nach Spülung des Geburtskanals mit Chlorhexidin

Maßnahmen zur Prävention einer neonatalen Sepsis mit Streptokokken der Gruppe B (GBS) sind aktive oder passive Immunprophylaxe sowie die Penicillingabe an Mütter und Kinder. In früheren Untersuchungen haben wir festgestellt, daß GBS hochempfindlich gegenüber Chlorhexidin sind. Darüberhinaus verminderte eine Vaginalspülung mit Chlorhexidin die Wachstumrate von GBS bei den Müttern. Um die Wirkung einer Chlorhexidinspülung auf die Kolonisierung der Neugeborenen zu untersuchen, wurde eine Gruppe von chronischen GBSTrägern, d. h. Frauen, die sowohl in der 32. und 36. 
Schwangerschaftswoche wie auch unter der Geburt GBS-positiv waren, zusammengestellt. Bei 18 Frauen wurde eine Chlorhexidinspülung vor der Entbindung durchgeführt; 33 Frauen dienten als Kontrolle. Bei 945 Frauen wurde ein GBS-Screening unter der Geburt durchgeführt. Bei allen Kindern wurden innerhalb der ersten 5 Minuten p. p. sowie am 4. Lebenstag Ohr-, Rachen- und Nabelabstriche gemacht. Bei der Geburt waren $22 \%$ der Kinder von Frauen nach Chlorhexidinspülung mit GBS kolonisiert, bei den Kindern chronischer GBS-Träger waren es dagegen $52 \%(\mathrm{p}<0.05)$. Am 4. Lebenstag war der Anteil von GBS-besiedelten Kindern in beiden Gruppen jedoch ähnlich (Tab. I). Unter den 945 Frauen mit Screening wurden 164 GBS- positive Patientinnen gefunden. Von den 164 Kindern waren $54(33 \%)$ bei der Geburt mit GBS kolonisiert. Somit ist die Kolonisierungsrate bei Kindern chronischer GBS-Träger signifikant höher, nämlich 17 von 33 Kindern $(p<0.05)$. Dies kann bedeuten, daß das Risiko einer GBS-Besiedlung der Kinder mit der Menge der Streptokokken im Geburtskanal steigt. Die Vaginalspülung mit Chlorhexidin hemmt bei den chronischen GBSTrägern die Übertragung von der Mutter auf das Kind. Nebenwirkungen der Spülung wurden nicht beobachtet. Die vorliegenden Ergebnisse zeigen die Möglichkeit auf, mit einer einfachen Maßnahme das Auftreten einer GBSErkrankung bei Neugeborenen zu kontrollieren.

\section{Schlüsselwörter: Chlorhexidin, neonatale Infektion, Streptokokken der Gruppe B.}

: :

\section{Résumé}

Diminution de la colonisation des nouvéaux-nés par le streptocoque du groupe $B$ après lavage des voies génitales par la chlorhexidine

Les mesures possibles pour prévenir les septicémies néonatales à streptocoques du groupe $\mathrm{B}$ (SGB) comprennent l'immunoprophylaxie active ou passive et l'administration de penicilline aux mères et aux enfants. Dans une étude antérieure, nous avons montré que les SGB sont très sensibles à la chlorhexidine. Bien plus, les lavages vaginaux à la chlorhexidine diminuent la recolonisation par les SGB chez les parturientes. On a selectionné un groupe d'étude de porteuses chroniques de SGB c'est-àdire des femmes SGB positives au cours de la grossesse entre 32 et 36 semaines et en cours de travail, afin d'étudier l'effet des lavages à la chlorhexidine chez 18 de ces femmes, avant l'accouchement, tandis que 33 porteuses chroniques ont servi de contrôles. On a réalisé un dépistage en cours de travail chez 945 patientes consécutives. Les prélèvements pour culture ont été effectués au niveau de l'oreille externe, de la gorge et de l'ombilic chez tous les enfants au cours des 5 premières minutes après la naissance et à 4 jours de vie. A la naissance, $22 \%$ des enfants dont les mères avaient subi des lavages à la chlorhexidine étaient colonisés par le $\mathrm{SGB}$, alors qu'à l'opposé, $52 \%$ des enfants des mères porteuses chroniques de SGB l'étaient $(p<0,05)$. Toutefois, la proportion d'enfants porteurs de SGB à jour 4 était similaire dans les 2 groupes (Tableau I). Parmi les 945 patientes ayant subi consécutivement un dépistage, 164 étaient porteuses de SGB, et $54(33 \%)$ de leurs 164 enfants étaient colonisés à la naissance. Ainsi le pourcentage d'enfants colonisés chez les porteuses chroniques de SGB était significativement plus élevé, 17 des 33 enfants $(p<0,05)$. Ce fait peut être le reflet d'un risque accru pour les enfants de contracter un SGB dans les voies génitales. Les lavages vaginaux à la chlorhexidine suppriment le transfert de SGB de la mère à l'enfant chez les porteuses chroniques de SGB. On n'a pas observé d'effets secondaires des lavages. Les résultats actuels augmentent l'espoir de promouvoir une mesure simple de contrôle du début précoce de la maladie néonatale à SGB.

Mots-clés: Chlorhexidine, infection néonatale, streptocoque du groupe B.

\section{Bịbliography}

[1] Ancona, R. J., P. Ferrieri, P. P. Williams: Maternal factors that enhance the acquisition of group B streptococci by newborn infants. J. Med. Microbiol. 13 (1980) 273

[2] BAKER, C. J.: Group B streptococcal infections. Adv. Intern. Med. 25 (1980) 475

[3] Christensen, K. K., P. Christensen, A.-K. Dykes, G. KAHLMETER, D. N. KURL, V. LINDEN: Chlorhexidine for prevention of neonatal colonization with group B streptococci. I. In vitro effect of chlorhexidine on group B streptococci.
Eur. J. Obstet. Gynaecol. Reprod. Biol. 16 (1983) 157

[4] Christensen, K. K., P. Christensen, I. HÄGERSTRAND, V. LINDEN, F. NoRDbRING, N. SVENNINGSEN: The clinical significance of group B streptococci. J. Perinat. Med. 10 (1982) 133

[5] Christensen, K. K., P. Christensen, K. DAHLANDER, A. Ekström, N. SVENNINGSEN: Colonization of newborns with group B streptococci: relation to maternal urogenital carriage. Scand. J. Infect. Dis. 13 (1981) 23 
[6] Dykes, A.-K., K. K. Christensen, P. Christensen, G. Kahlilmeter: Chlorhexidine for prevention of neonatal colonization with group B streptococci. II. Chlorhexidine concentrations and recovery of group B streplococci following vaginal washing in pregnant women. Eur. J. Obstet. Gynaccol. Reprod. Biol. 16 (1983) 167
[7] Lancefield, R. C., M. McCarty, W. N. Everly: Multiple mouse-protective antibodies directed against group B streptococci. J. Exp. Med. 142 (1975) 165

Received August 27, 1984. Accepted January 21, 1985.

Dr. Karen Kvist Christensen

Dept. Obstetrics and Gynecology University Hospital

S-221 85 Lund, Sweden 


\section{Biochemical and Clinical Aspects

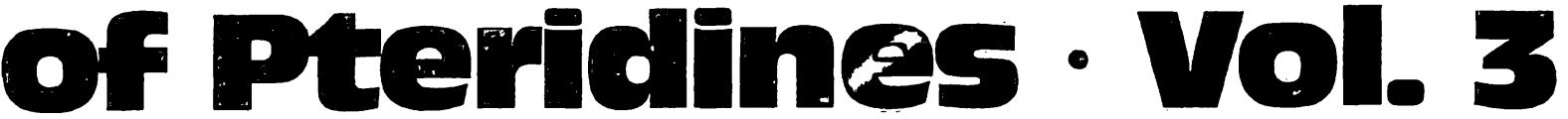

Cancer · Immunology · Metabolic Diseases

Proceedings · Third Winter Workshop of Pteridines · February 18-25, 1984, St. Christoph, Arlberg, Austria

Editors W. Pfleiderer, H. Wachter, H. Ch. Curtius

1984. $17 \mathrm{~cm} \times 24 \mathrm{~cm}$. XII, 514 pages. Numerous illustrations. Hardcover. DM 220,ISBN 3110101637

The papers in this book are a continuation of the topics dealt with in volumes 1 and 2 . Besides the presentation of chemical and photochemical aspects of pteridines, progress is reported especially in the field of tetrahydrobiopterin biosynthesis and the functions of various pteridine derivatives in the animal and plant kingdoms.

Also available

\section{Biochemical and Clinical Aspects of Pteridines - Vol. 1}

Editors $H$. Wachter, $H$. Ch. Curtius, W. Pfleiderer

1982. XV, 373 pages. DM 150,-

\section{Bioapemiegl and Clinical Aspects of Pteridines - Vol. 2}

Editors H. Ch. Curtius, W. Pfleiderer, H. Wachter 1983. XV, 435 pages. DM 190,-

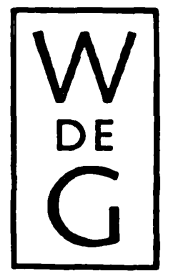

de Gruyter · Berlin · New York 